\title{
PRINCIPAL EARTHQUAKES DURING THE YEAR 1976
}

\author{
R. D. Adams*
}

1976 saw the largest New Zealand earthquake for eight years and a variety of smaller shocks. Although the Seismological Observatory located several hundred earthquakes of magnitude 4 and greater on the Richter Scale, only a proportion of the larger ones, and those near centres of population, were reported felt, and no earthquake caused serious damage.

The earthquake early on the morning of 5 May, 1976 had a magnitude of 7.0, and was the largest since that at Inangahua in 1968, which had a magnitude of 7.1 . It occurred near the coast of Fiordland, about $35 \mathrm{~km}$ west of Milford Sound. The earthquake was felt throughout the southern half of the South Island, and caused some landslides in the steep country near the epicentre, but because of its remoteness, it caused no significant damage and attracted little publicity. Other earthquakes felt in the far south of the country occurred to the southwest of Stewart Island on 8 January (magnitude 5.8) and near Solander Island on 5 March (magnitude 5.4).

Earthquake activity in the North Island was notable for a series of swarms of shallow earthquakes. The most significant occurred in Hawkes Bay, about $20 \mathrm{~km}$ south of Wairoa. Two earthquakes seven minutes apart on the morning of 21 March both had magnitudes of 5.6, and two others in the next 24 hours had magnitudes of 5.4 and 5.3. Within the following few days about 30 earthquakes of magnitude greater than 4, and an even larger number of smaller shocks, were recorded. Many chimneys were damaged at Wairoa, where there was also some minor structural damage. There were isolated instances of minor damage from as far afield as Napier.

The area around Tauranga and Te Puke was subject to swarms of small shallow earthquakes from late in August until the end of October. The largest shock of the sequence was that of 28 October, which although of magnitude only $43 / 4$ caused some substantial damage in a small area near Roydon Downs about $10 \mathrm{~km}$ southeast of Te Puke. An even smaller earthquake (magnitude 3.8 ) is also reported to have caused some damage in the same area on 9 september. The strong effects of these small earthquakes in localised areas close to their epicentres may be attributed to their very shallow depth. On 5 April a similar swarm of very shallow shocks was felt at Atiamuri, where goods were dislodged from shelves although the greatest magnitude was only 2.6 .

Individual shallow earthquakes in the North Island that were felt widely included a shock of magnitude 5.5 near Carterton on

\footnotetext{
* Superintendent, Seismological observatory,
} Wellington.
30 January, and one of magnitude 5.0 near Te Awamutu on 5 December. The latter shock caused some minor damage. An earthquake of magnitude 5.1 in Westland on 18 July was felt strongly at Ross.

Deep earthquakes that were felt extensively occurred on 15 May (magnitude 6.1) and on 23 December (magnitude 6.3). Both occurred several hundred kilometres beneath the Bay of Plenty. The first was felt in the East Cape peninsula and parts of Hawke's Bay, and there were isolated reports of the second earthquake being felt as far south as the Wellington region. Because of the depth of these earthquakes, the intensities were not high.

An unusually situated earthquake occurred on 28 December about $450 \mathrm{~km}$ west of Westport. This is the first earthquake definitely located in this region, but its position on the southwestern flank of the Lord Howe Rise is not without parallel, for other earthquakes have occurred on marine ridges extending into the Tasman sea to the north and west of Northland. The earthquake had a moderate magnitude (5 1/4), and was followed by some smaller aftershocks, but because of its distance from the coast was not reported felt.

A series of large earthquakes occurred in January near Raoul Island, about $1000 \mathrm{~km}$ northeast of New Zealand. A shock of magnitude $7 \frac{1}{2}$ on 2 January was followed by two even larger earthquakes of magnitude about $73 / 4$ on the morning of 15 January. These shocks generated a small tsunami, which was noticed on the east coast of Northland. There was damage to roading and water supplies at the Meteorological station on Raoul Island; the station buildings were slightly damaged and some instruments put out of action, but there were no casualties. A further shock, of magnitude $63 / 4$, occurred on 5 May.

The central North Island volcanoes were relatively quiet during the year, and no significant eruptions occurred from either Mt Ruapehu or Mt Ngauruhoe. 